\title{
An Anionic Non-Aqueous Single Substance Redox Flow Battery Based on Triiodide
}

\author{
Niklas Heiland $\neq$ Mathias Piescheck $\neq$, Uwe Schröder* \\ Institute of Environmental and Sustainable Chemistry, Technische Universität Braunschweig, \\ Hagenring 30, 38106 Braunschweig, Germany \\ *E-mail: uwe.schroeder@tu-braunschweig.de \\ \$ Both authors contributed equally.
}

doi: $10.20964 / 2016.11 .14$

Received: 28 June 2016 / Accepted: 29 August 2016 / Published: 10 October 2016

\begin{abstract}
A single-substance redox-flow battery (RFB) based on the iodide/triiodide and triiodide/iodine redox couples has been investigated. Stable charge-discharge curves were recorded under ambient air in a stirred PTFE batch cell. Current efficiencies were $>90 \%$. Current densities were kept low $(33 \mu \mathrm{A}$ $\left.\mathrm{cm}^{-2}\right)$ due to high resistance $\left(5.8 \mathrm{k} \Omega \mathrm{cm}^{2}\right)$ of the cation exchange membrane used. It is shown theoretically, that the open voltage potential $E_{O C}$ of redox flow batteries with complex stoichiometry is concentration dependent. For comproportionation electrolytes, the $E_{O C}$ increases with bulk concentration, which is proved experimentally for the $\mathrm{I}^{-} / \mathrm{I}_{3}^{-} / \mathrm{I}_{2}$ system. The open cell voltage ranged from $0.36 \mathrm{~V}$ to $0.58 \mathrm{~V}$ for $1-80 \mathrm{mM}$ solutions. The formal potential difference $\Delta E^{0^{\prime}}$ was determined by cyclic voltammetry $(0.655 \mathrm{~V})$ and open cell voltages $(0.69 \mathrm{~V})$, respectively. Interestingly, the calculation of $\Delta E^{0^{\prime}}$ required the evaluation of the open cell voltage at a state of charge of the inverse of the golden number. This is a consequence of the "golden" stoichiometric factors of the iodide/iodine comproportionation.

To the authors' knowledge, this is the first report of a non-aqueous redox-flow battery utilizing an anionic catholyte and thus also the first where only anionic or neutral redox active species are employed.
\end{abstract}

Keywords: redox-flow battery; non-aqueous; triiodide; comproportionation; stoichiometry

\section{FULL TEXT}

(C) 2016 The Authors. Published by ESG (www.electrochemsci.org). This article is an open access article distributed under the terms and conditions of the Creative Commons Attribution license (http://creativecommons.org/licenses/by/4.0/). 